force $2 \frac{1}{2}$ times that of a Daniell's cell; their internal resistance was also very. small, being from one-eighth to one-twentieth of an ohm. These cells improved with use; the liberated gases attacking the surface of the lead electrodes, so that they gradually became of a spongy texture, while the surface of the plate at which oxygen was liberated became covered with a film of brown peroxide of lead. When both electrodes were thus "formed" by charging the cell at intervals of a few days in opposite directions, the Planté cell became a veritable accumulator

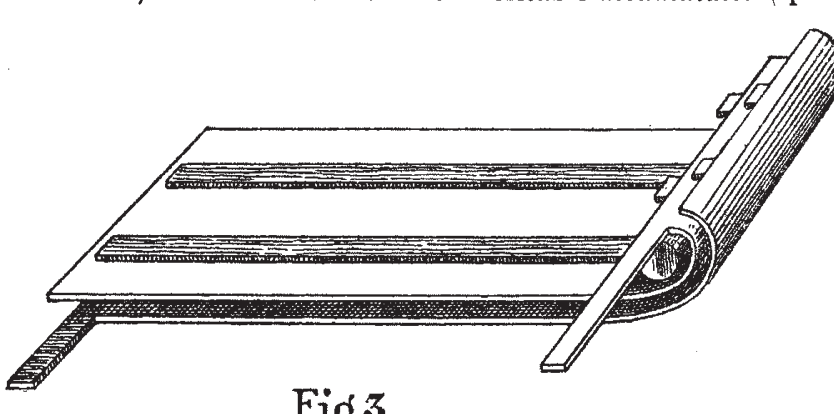

Fig 3

Represents two sheets of lead, separated by strips of thick felt, prepared for rolling together round a roller.

of electric currents, and was able to store up from a comparatively feeble source a supply which could yield vastly stronger effects for a short time. In fact the secondary battery became in Plante's hands a kind of Leyden-jar for storing currents of electricity; the essential point of difference between the two being that while the Leydenjar accumulates a charge, and can be charged or discharged in an instant-or in other words possesses only an "instantaneous capacity"-the secondary battery accumulate currents which may flow into it for many hours, and which may take also a considerable time for their discharge, its "continuous capacity" being very great as compared with its instantaneous capacity. The currents stored up in the secondary battery are however not stored up as accumulations of electricity. They are stored up in the form of chemical work done in the cell, this chemical work being capable of being retransformed at will into the energy of electric currents. When the charging current from an independent battery or from a dynamo-electric machine (see Fig. 2) is passed through a Planté cell, the electrode by which the current enters becomes more bighly peroxidised than before, while a corresponding amount of deoxidisation takes place at the electrode by which the current leaves the cell. When the cell thus charged is used as a battery it gives back a current which flows out from the electrode by which it formerly flowed in ; passing through the cell from the deoxidised to the peroxidised electrode, until they are both reduced to a state of chemical similarity. If the cell is joined to the dynamomachine which charged it, in order to drive it round as an electro-magnetic engine or motor, it will cause it to rotate in the same direction as that in which it was driven when used as a generator; the principle of reversibility applying both to the cell and to the machine.

Several forms of secondary battery adapted for storage of currents have been suggested in recent years. In Philadelphia Professors Houston and E. Thomson have tried a modification of the Daniell's cell, in which sulphate of zinc was electrolysed between electrodes of copper, the metallic zinc so deposited afterwards serving as the negative pole of the cell. Another suggestion, due to $M$. d'Arsonval, was to use an electrode of lead along with one of zinc, dipping into a solution of sulphate of zinc. The charging currents deposited metallic zinc upon the latter and liberated oxygen at the former, which, as in the Planté cell, became coated with spongy peroxide of lead. As this latter is not a very good conductor M. d'Arsonval further proposed to increase the effective surface by laying the sheet of lead horizontal and covering it with leaden shot, which should also become peroxidised.

The latest form of secondary battery is that of $M$. Camille Faure, described in NATURE, vol. xxiv. p. 68, of which there has been so much talk in the semi-scientific press, and which is now being made the central point of a great financial "operation" in Paris. There can be no doubt that this instrument, though the accounts of its performances have been grossly exaggerated, is an improvement upon that of Planté, of which it is a slight modification. The labour and difficulty of "forming" the Plante cell, that is to say of charging and recharging it until a sufficient film of peroxide of lead should be produced, led M. Faure to try the effect of coating the lead plates at first with a film of red lead or minium, a lower oxide than the dark brown peroxide. The two sheets, after having been covered with minium, are rolled together precisely as in the Planté cells, as shown in Fig. 3, a sheet of felt being interposed to prevent internal contact. It was stated by $M$. Reynier that the captcity of such cells was forty times that of the Planté cell; but four times would have been nearer the mark if cells of equal size were compared. M. Faure's cells are made of large size and weigh 75 kilogrammes, or nearly 200 lbs. It is stated th it one such cell would store a sufficient amount of current as to be able afterwards to yield in an hour an amount of work equal to one horsepower. Confirmatory observations are yet needed. Meantime let us just remind the enthusiast who brought over to England the "million foot-pounds" of energy stored up in a Faure cell, that he would have imported a dozen times as much stored energy if he had brought over instead a lump of coal of the same weight.

The uses for such secondary batteries may be of three kinds:-1. They may serve as portable supplies of electricity to be left and called for to recharge when exhausted. 2. They may serve to accumulate supplies of electricity from dynamo-electric machines, and store them until required for furnishing electric light or motive power on a small scale. 3. They may serve as equalisers of electric currents in a system in which the supply is liable to fluctuations. Suppose, for example, a dynamo-electric machine is employed to produce electric light. Any least thing which alters the speed of the machine, even for an instant, makes the light flicker and change in intensity; while the breakage of the engine-strap would at once cause total darkness. But if a secondary battery of suitable dimensions and power were inserted across the circuit between the dynamo-machine and the lamp, the inequalities of the current would be greatly modified. When the light was not in use the battery would store up the current. If the engine failed the battery would at once put forth its power. It is probably in this direction that the secondary battery will find no unimportant field of usefulness.

\section{A SINGULAR CASE OF SHIPWRECK}

THE wreck of the Danish mail steamer Phonix, which took place off the west coast of Iceland on January 29 , was attended by rather unusual circumstances deserving of note. The vessel (about 450 tons burden) sailed with cargo and the mails from Copenhagen for Leith, the Faröe Islands, and Iceland, about the middle of January.

Nothing particular occurred until after leaving the Faröes, when she ran into a severe gale, which rapidly increased to a perfect hurricane, while at the same time the temperature fell to about $50^{\circ} \mathrm{F}$. of frost $\left(-I 8^{\circ} \mathrm{F}\right.$.). Such cold is not extraordinary in these latitudes in winter, but fortunately it is seldom associated with very high winds. Under the circumstances in which the Phonix was placed every sea that she shipped froze, and the deck soon became covered with a foot or two of solid ice. 
As time passed on the continued action of the sea raised a perfect iceberg on the forward part of the vessel, while the showers of spray carried along by the steadily increasing gale covered the masts, yards, and rigging with an ever-thickening coating of ice. Two or three days passed without the least abatement of the storm, and then the half-smothered steamer went over on her beam ends. The crew succeeded in cutting away the masts, and she once more righted.

It however was clear, the gale showing no signs of breaking, that the relief was only temporary. The ice continued to form on the vessel, particularly about the forecastle, where, piled high above the bulwarks, and overbanging the sides, it threatened, by altering her trim, to raise the propeller out of the water.

Under these circumstances, on the morning of January 29, Capt. Kihl decided to run the steamer ashore while daylight lasted. At some distance from the land she struck on a sunken rock, and the crew, taking to the boats, only succeeded with the greatest difficulty in reaching the shore, saving nothing but their lives, the English mail, and a bundle of blankets which (when carried ashore) was found to be useless-frozen into a solid lump. Their situation in deep snow on the desolate coast of Iceland, about Ioo miles to the north-west of Reykjavik, was very critical, and a party of two or three of the stronger sailors under the command of M. Jaspersin, the first officer, proceeded in search of assistance. It was not however until about three in the morning of the 3oth, after suffering great hardships, that the sound of a pony kicking in a shed guided them to a house. The farmers immediately turned out, and eventually the scattered crew, twenty-two or twenty-three in number, were picked up, some of the clever little Icelandic dogs proving themselves most valuable auxiliaries in the search. Many of the men, however, were all but frozen to death in the snow. From this time all possible attention was given to them; but one, having both legs and arms frost-bitten, died; another afterwards had both legs amputated below the knees; and the steward lost three

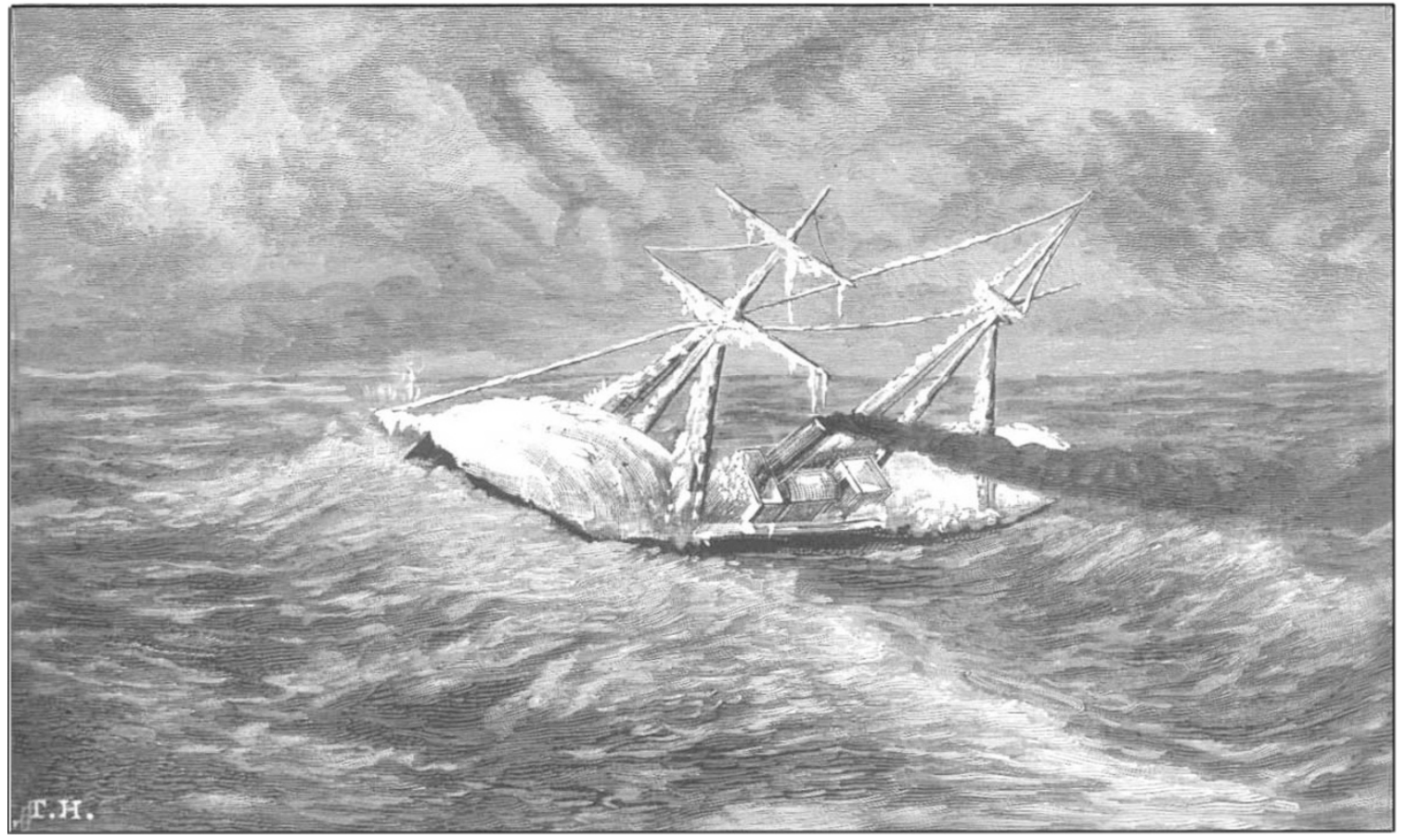

fingers of each hand. Hardly one escaped more or less injury from the effects of the extreme cold to which they had been so long exposed. Capt. Kihl and the bulk of his crew soon after succeeded in getting to Reykjavik, and on April 13 they sailed in the sister steamer, the Arcturus, for Copenhagen. The officers and men of the wrecked vessel are of opinion that had Capt. Kihl not decided on the 29 th to run the Phonix ashore in daylight not a soul would have been saved, as the gale did not moderate for several days after; and the steamer, buried as it was under an enormous mass of ice, must have foundered in the night.

In Iceland this storm will be long remembered by the destruction it caused; and it is said that such a terrible winter has not been known for years. Sheep have perished in large numbers, and ponies have been killed to save hay. Then as the Icelanders depend on the outer world for flour, \&c., the loss of the Phonix with its cargo was a terrible misfortune. A letter from Reykjavik to a lady in Edinburgh, published on April 2 I (and dated the
Ioth), states that the magazines were empty, and concludes thus: "It was very delightful to see the steamer Arcturus coming in the other day after having expected it so long. It brought both news and provisions, so that the poor people in the neighbourhood of Reykjavik can be helped for a while."

J. Allen Allen

\section{NOTES}

CAPt. Frederick John OWen Evans, C.B., F.R.S., has been made a K.C.B. Among all the crowd of names gazetted for such bonours on the Queen's birthday, not one had better deserved it by his services to his country, as well as to science, than the well-known Hydrographer to the Admiralty.

THE Visitation of the Royal Observatory takes place on Saturday. No doubt it will be numerously attended, as it is announced that Sir George Airy has resigned his post for the Ist of August. 